\title{
Perioperative Prognostic Value of N-Terminal Pro-Brain Natriuretic Peptide (NT- proBNP) Level in Patients Undergoing Open Heart Surgery
}

\author{
AHMED M.M. HAMED, M.Sc.; MOHAMED M. ABO EL-NASR, M.D.; EL-ATAFY E. EL-ATAFY, M.D. and \\ ABD EL-HADY M. TAHA, M.D.
}

The Department of Cardiothoracic Surgery, Faculty of Medicine, Tanta University

\begin{abstract}
Background: In this article, we examined the relationship between the pre- and postoperative $\mathrm{N}$-terminal pro-brain natriuretic peptide (NT-proBNP) levels and occurance of complications in patients undergoing open heart surgery.
\end{abstract}

Aim of Study: To find out the prognostic value of NTproBNP as a valuable marker in predicting postoperative myocardial insult, short term outcome in patients undergoing open heart surgery and evaluate the independency of this biomarker.

Patients and Methods: It was carried out on 105 patients who had cardiac surgery in our department from April 2016 to August 2017. All patients had preoperative and postoperative ECG, Echocardiography and full investigations. Venous blood samples were drawn for estimation of serum level NT-pro BNP by ELISA one hour prior to the operation and 24 hours after the operation. Intraoperative and postoperative data include cardiopulmonary bypass time, aortic cross clamping time, requirement for cardiac support immediately after the operation, ICU and hospital stay and occurance of postoperative complications.

Results: There was highly statistically significant difference between preoperative and postoperative NT-proBNP $(p<0.001)$. Also, we found a significant relation between postoperative NT-proBNP and need of inotropes immediately after operation $(p=0.035)$. Patients who had prolonged ICU stay and hospitalization had significantly higher postoperative NT-proBNP levels with $(p<0.001)$ and $(p=0.009)$ respectively. Our results showed that there was a significant relationship between postoperative NT-proBNP and most of postoperative complications $(p<0.001)$

Conclusion: NT-proBNP levels strongly correlated with postoperative complications, suggesting its value as a useful prognostic predictor after cardiac surgery which can predict early outcome after cardiac surgery. NT-proBNP levels may be an option when an echocardiogram is not feasible and inotropes may be needed, especially if these levels can be measured in the patient's bed. So, NT-proBNP may become

Correspondence to: Dr. Ahmed M.M. Hamed,

The Department of Cardiothoracic Surgery,

Faculty of Medicine, Tanta University a clinical routine biomarker capable of predicting patients' perioperative and early postoperative risk because of it is convenient, quick and not expensive. The quantitative cutoff values may be used by physicians in their decision to delay heart surgery in order to further ameliorate the patient.

Key Words: NT-proBNP - Cardiac surgery - Inotropes Complications.

\section{Introduction}

BRAIN natriuretic peptides (BNPs) are cardiac hormones released by ventricular myocytes in response to ventricular dysfunction and wall stress. It is named as such because it was originally identified in extracts of porcine brain, although in humans it is produced mainly in the cardiac ventricles and atria $[\mathbf{1 , 2}]$

Brain naturetic peptides are finally cleaved into the biologically active mature BNP and the biologically inactive NT-proBNP, which are released into the blood stream, both are established as cardiovascular biomarkers, especially in heart failure, hypertension, acute coronary syndrome or stable ischemic cardiac disease having diagnostic and prognostic values. It was found that it is related to increase in intraventricular pressure and its level rises by the effect of cardiopulmonary bypass $[3,4]$.

Theoretically it was found that NT-pro BNP have analytical advantages over mature BNP due to its longer half life furthermore, it could be analyzed 72 hours after the sample has been taken. $[5,6]$.

Aim of the work: Is to find out the prognostic value of NT-proBNP as a valuable marker in predicting postoperative myocardial insult, short term outcome in patients undergoing open heart surgery and evaluate the independency of this biomarker. 


\section{Patients and Methods}

This study was carried out on a randomly selected 105 patients who had cardiac surgery in our department from April 2016 to August 2017.

Exclusion criteria were: Patients with acute renal failure, preoperative insertion of intra-aortic balloon, off-pump open heart surgery and ejection fraction less than $30 \%$.

\section{All patients were subjected to:}

A- Full history taking and thorough clinical examination.

B- Investigations: Complete blood count, liver function tests, urea, creatinine, $\mathrm{LDH}$, Troponin and CK-MB.

C- Preoperative and postoperative ECG and Echocardiography.

D- Estimation of serum level NT-pro BNP by ELISA one hour prior to the operation and 24 hours after the operation: [7].

- NT-Pro BNP was analyzed using a commercial NT-pro BNP ELISA Kit (Biomedica, Vienna, Austria).

- Venous blood was obtained by direct venipuncture and collected into serum separator tubes. Samples were centrifuged within $20 \mathrm{~min}$ from sampling. Serum was stored frozen at $-20^{\circ} \mathrm{C}$ and thawed only once at the time of analysis.

\section{Results}

Table (1): Shows that 12 patients had aortic valve replacement, 9 patients had mitral valve replacement, 3 patients had tricuspid valve replacement, 51 patients had CABG surgery, 3 patients had double valve replacement and 21 patients had combined surgery.

Table (2): Shows that the mean age of patients was $43.17 \pm 12.79$ (range 22-68 years) with female predominance of the patients.

Table (3): Show that there were 3 patients died after one week postoperative $(2.9 \%)$.

Table (4): Shows significant difference between NT-proBNP with age, Duration of ventilation dependence, CPB time, Aortic cross clamp, ICU stay, hospital stay and postoperative creatinine when $p$ value was $<0.05^{*}$ while was non statistically significant difference with others items when $p$-value was $>0.05$.
Table (5): Shows that non significant relation between postoperative NT-proBNP and bradycardia when when $p$-value was $>0.05$ while was significant relation with other complications when $p$-value was $<0.05$.

Table (1): Type of operation.

\begin{tabular}{lcc}
\hline Type of operation & $\mathrm{N}$ & $\%$ \\
\hline AVR & 12 & 11.4 \\
CABG & 51 & 20.0 \\
DVR & 3 & 8.6 \\
MVR & 9 & 37.1 \\
TVR & 3 & 2.9 \\
Combined: & & \\
AVR \& CABG & 3 & 2.9 \\
MVR \& CABG & 3 & 2.9 \\
MVR \& Devaga & 12 & 11.4 \\
MVR \& AVR\& Devaga & 3 & 2.9 \\
\hline
\end{tabular}

Table (2): Demographic data (age and sex).

\begin{tabular}{|c|c|c|}
\hline & \multicolumn{2}{|l|}{ N. $(\%)$} \\
\hline \multicolumn{3}{|l|}{ Age (years): } \\
\hline Range & \multicolumn{2}{|l|}{$22-68$} \\
\hline Mean \pm SD & \multicolumn{2}{|l|}{$43.17 \pm 12.79$} \\
\hline \multicolumn{3}{|l|}{ Sex: } \\
\hline Female & \multicolumn{2}{|l|}{$63(60 \%)$} \\
\hline Male & \multicolumn{2}{|l|}{$42(40 \%)$} \\
\hline Total & \multicolumn{2}{|l|}{$105(100 \%)$} \\
\hline \multicolumn{3}{|c|}{ Table (3): Death within 30 days of surgery } \\
\hline Death within 30 days of surgery & $\mathrm{N}$ & $\%$ \\
\hline Alive & 102 & 97.1 \\
\hline Died & 3 & 2.9 \\
\hline Total & 105 & 100.0 \\
\hline
\end{tabular}

Table (4): Correlation between postoperative NT-proBNP and other items.

\begin{tabular}{lcc}
\hline & \multicolumn{2}{c}{ Post NT-proBNP } \\
\cline { 2 - 3 } & $r$ & $p$-value \\
\hline Age & 0.327 & $0.002^{*}$ \\
Duration of ventilation dependence & 0.508 & $<0.001^{* *}$ \\
ICU stay & 0.674 & $<0.001^{* *}$ \\
Hospital stay & 0.434 & $0.009^{*}$ \\
EF \% post & 0.062 & 0.529 \\
CPB time & 0.658 & $<0.001^{* *}$ \\
Aortic cross clamp & 0.601 & $<0.001^{* *}$ \\
Creatinine post & 0.433 & $<0.001 * *$ \\
\hline
\end{tabular}


Table (5): Relation between postoperative NT-proBNP and postoperative complication.

\begin{tabular}{lcccccc}
\hline \multirow{2}{*}{ Complication } & \multicolumn{7}{c}{ Post NT-proBNP } \\
\cline { 2 - 7 } & \multicolumn{7}{c}{ No } & \multicolumn{2}{c}{ Yes } & $t$-test \\
\cline { 2 - 7 } & $\mathrm{N}$ & Mean \pm SD & $\mathrm{N}$ & Mean $\pm \mathrm{SD}$ & $t$ & $p$-value \\
\hline Neurological & 96 & $2540.47 \pm 493.17$ & 9 & $3436.67 \pm 363.35$ & 5.308 & $<0.001 * *$ \\
Renal & 90 & $2663.27 \pm 723.39$ & 15 & $3621.40 \pm 806.59$ & 4.673 & $<0.001 * *$ \\
Pulmonary & 99 & $2445.30 \pm 780.33$ & 6 & $3705.00 \pm 700.04$ & 3.858 & $<0.001 * *$ \\
Wound infection & 78 & $2676.00 \pm 781.42$ & 27 & $3158.78 \pm 781.71$ & 2.767 & $0.007^{*}$ \\
AF & 87 & $2091.06 \pm 806.60$ & 18 & $2950.00 \pm 919.24$ & 4.015 & $<0.001 * *$ \\
Bradycardia & 99 & $2791.97 \pm 820.88$ & 6 & $2935.00 \pm 332.34$ & 0.423 & 0.673 \\
Pericardial effusion & 102 & $2773.68 \pm 795.42$ & 3 & $3700.00 \pm 462.37$ & 2.001 & $0.048^{*}$ \\
\hline
\end{tabular}

\section{Discussion}

In the present study we found a great variability in NT-proBNP levels. Our study design was restricted to adult cardiac surgery and occasionally we found female predominance of the patients.

In this study, there was highly statistically significant difference between preoperative and postoperative NT-proBNP with $p$-value $<0.001$. This is in agreement with Chen $\mathrm{T}$ et al and Liu $\mathrm{H}$ et al., who reported that NT-proBNP levels increase 24 hours after the operation. This may be attributed to that BNP is synthesized and secreted from cardiomyocytes in response to atrial or ventricular wall stretch $[1,8]$.

Our results showed that there was a significant relation between postoperative NT-proBNP and need of inotropes immediately after operation. This is in accordance with Reyes $\mathrm{G}$ et al who showed that NT-proBNP levels were much higher in those patients that required inotropes in theatre or immediately after operation during their stay in the intensive unit care [9].

We also found a significant relationship between NT-proBNP and age. This is in agreement with Attaran S et al who said that NT- proBNP levels increase with age because there is a reduction in the natriuretic peptide clearance with aging [10]

There was a significant relationship between NT-proBNP and duration of ventilation dependence. Similarly, Shih C et al., showed that high NTproBNP levels predicted longer ventilation time [11].

In our study, there was a significant relationship between NT-proBNP and both CPB time and aortic cross clamp. This is in agreement with Junior $\mathbf{J}$ et al., due to the ischemia caused by prolonged crossclamp time. On the contrary, Reyes $\mathrm{G}$ et al., report- ed that NT-proBNP levels were unrelated to both bypass and cross clamp time $[\mathbf{9 , 1 2}]$.

In our study, we demonstrated that there was a significant relation between NT-proBNP and both prolonged ICU stay and hospitalization. This is in agreement with Chen $\mathrm{T}$ et al., who reported that the postoperative Day 1 NT-proBNP was significantly higher in patients with prolonged ICU stay and hospitalization. We also found that there was a significant relation between NT-proBNP and postoperative creatinine. This is in accordance with Bucholz E et al who reported that high NT-proBNP level was associated with impaired renal function. $[8,13]$.

We found that there was no significant relation between NT-proBNP and ejection fraction. This is in agreement with Salustri A et al., [14] . But, on the contrary Kabukçu $\mathrm{H}$ et al reported that there was a significant relation between NT-proBNP and ejection fraction [15]. One reason for this finding could be the optimal treatment of our patients before surgery, as it is well known that NT-proBNP levels may vary depending on the quality of medical treatment [16].

Finally, in the present study we found that postoperative NT-pro BNP predicted most of postoperative complications. This is in agreement with many studies like Lara $\mathrm{T}$ et al., and Tavakol $\mathrm{M}$ et al., whereas Reyes $\mathrm{G}$ et al., reported that there was no any significant relation between NT-proBNP and the appearance of complications after surgery. $[\mathbf{9 , 1 7 , 1 8 ]}$

\section{Conclusion:}

NT-proBNP levels strongly correlated with postoperative complications, suggesting its value as a useful prognostic predictor after cardiac surgery which can predict early outcome after cardiac surgery. 
NT-proBNP levels may be an option when an echocardiogram is not feasible and inotropes may be needed, especially if these levels can be measured in the patient's bed. So, NT-proBNP may become a clinical routine biomarker capable of predicting patients'perioperative and early postoperative risk because of it is convenient, quick and not expensive.

Acknowledgments: This research was carried out without funding.

Conflicts of interest: No conflicts of interest declared.

Authors' Contributions: All authors had equal role in design, work, statistical analysis and manuscript writing. All authors have approved the final article work.

\section{References}

1- LIU H., WANG C., LIU L., et al: Perioperative application of $\mathrm{N}$-terminal pro-brain natriuretic peptide in patients undergoing cardiac surgery. J. Cardiothorac. Surg., 8: 1, 2013.

2- DE LEMOS J.A., MCGUIRE D.K. and DRAZNER M.H.: B-type natriuretic peptide in cardiovascular disease. Lancet, 362: 316-322, 2003.

3- HOUBEN A.J., VAN DER ZANDER K. and de LEEUW P.W.: Vascular and renal actions of brain natriuretic peptide in man: Physiology and pharmacology. Fundarn. Clin. Pharmacoi., 19: 411-419, 2005.

4- STESNER J. and GUGLIN M.: BNP or MTproBNP? A clinician's perspective. Int. J. Cardiol., 129: 5-14, 2008.

5- HUNT P.J., RICHARDS A.M., NICHOLLS M.G., et al: Immunoreactive amino-terminal pro-brain natriuretic peptide (NT-PROBNP): A new marker of cardiac impairment. Clin. Endocrinol. (Oxf), 47: 287-296, 1997.

6- KOTASKA K., POPELOVA J., TISEROVA M., et al: NT-proBNP AND BNP Values In Cardiac Patients With Different Degree Of Left Ventricular Systolic Dysfunction. Biomed Pap Med Fac Univ. Palacky. Olomouc. Czech. Repub., 150 (1): 125-130, 2006.

7- SCHULZ H., LANGVIK T.A. and LUND S.E.: Radioimmunoassay for $\mathrm{N}$-terminal probrain natriuretic peptide in human plasma. Scand. J. Clin. Lab. Invest., 61: 33-42, 2001.
8- CHEN T., LIN C., SHIH J., et al.: Plasma B-type natriuretic peptide in predicting outcomes of elective coronary artery bypass surgery, Kaohsiung Journal of Medical Sciences, 29: 254-258, 2013.

9- REYES G., FORES G., ABELLA R., et al.: NT-proBNP in cardiac surgery: A new tool for the management of our patients?, Interactive CardioVascular and Thoracic Surgery 4: 242-247, 2005

10- ATTARAN S., SHERWOOD R., DESAI J., et al.: Brain natriuretic peptide a predictive marker in cardiac surgery, Interactive CardioVascular and Thoracic Surgery, 9: 662666, 2009.

11- SHIH C., SAPRU A., OISHI P., et al.: Alterations in plasma B-type natriuretic peptide levels after repair of congenital heart defects: A potential perioperative marker, J. Thorac. Cardiovasc. Surg., 131: 632-8, 2006.

12- JUNIOR J., NAKAZONE M., MACHADO M., et al.: Predictors of mortality in cardiac surgery: Brainnatriuretic peptide type B. Braz. J. Cardiovasc. Surg., 30 (2): 1827, 2015.

13- BUCHOLZ E., WHITLOCK R., ZAPPITELLI M., et al.: Cardiac Biomarkers and Acute Kidney Injury After Cardiac Surgery Pediatrics, 4: 135, 2015.

14- SALUSTRI A., CERQUETANI E., PICCOLI M., et al.: Relationship between B-type natriuretic peptide levels and echocardiographic indices of left ventricular filling pressures in post-cardiac surgery patients, Cardiovascular Ultrasound, 7: 49, 2009.

15-KABUKÇU H., ŞIMŞEK S., ŞAHIN N., et al.: Comparison of the NT-proBNP levels between coronary artery bypass grafting patients and concomitant coronary artery bypass grafting with valve replacement patients, Türk. Gög üs. Kalp. Damar. Cer. Derg., 18 (4): 271-276, 2010.

16- TROUGHTON R.W., FRAMPTON C.M., YANDLE T., et al.: Treatment of heart failure guided by plasma amino terminal brain natriuretic peptide concentrations. Lancet, 355: 1126-1130, 2000.

17- LARA T., HAJJAR L., ALMEIDA J., et al.: High levels of B-type natriuretic peptide predict weaning failure from mechanical ventilation in adult patients after cardiac surgery, Clinics (Sao Paulo), 68 (1): 33-38, 2013.

18- TAVAKOL M., HASSAN K., ABDULA R., et al.: Utility of Brain Natriuretic Peptide as a Predictor of Atrial Fibrillation After Cardiac Operations, Ann. Thorac. Surg., 88: 802-8, 2009. 


\section{القيمة التنبوئية لمستوى (أن تى- بروبى أن بى) قبل وبعد الجراحة الجموية

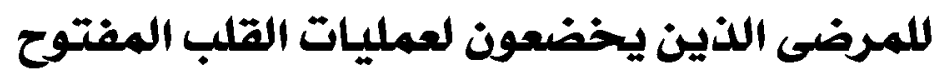

$$
\text { وجد أن المضاعفات الرئيسية ما بعد جراحة القلب يمكن أن تؤثر بشكل كبير على النتائج. }
$$

لذلك فإن التشخيص المبكر والتصنيف الد قيق المخاطر هما من المسائل المهمة لتطوير أهداف علاجية يمكن أن تحسن رعاية المرضى. لذلك إستخدام دلالات القلب كمنبؤات على حدوث مضاعفات القلب على المدى القصير والطويل سيكون مفيدا فى الممارسة السريرية الروتينية. البيتيدات المخية المدرة للصوديوم (بى أن بى) هى هرمونات قلب يتم إفرازها أساساً من البطينين رداً على التحفيز المناسب ومن ثم تنقسم اليتيدات إلى (بى أن بى) و (أن تى- برو بى أن بى) الذى الذى يعد أكثر أستقراراً وقياسه أكثر موضوعية.

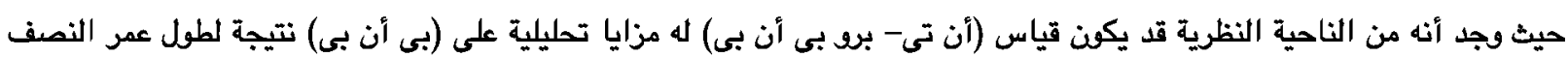

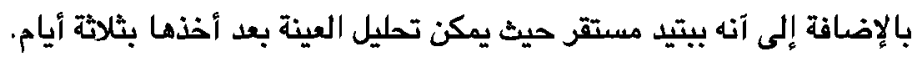

الهدف من الدراسة: معرفة القيمة التتبوئية الخاصة ب (أن تى - برو بى أن بى) كدلالة على مضاعفات عضلة القلب بعد العملية الجراحية

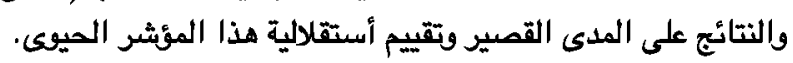

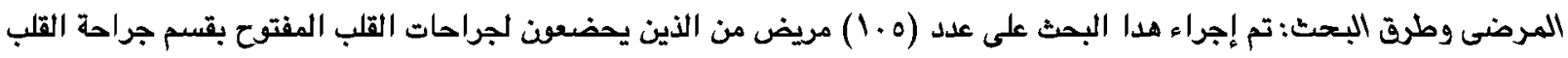

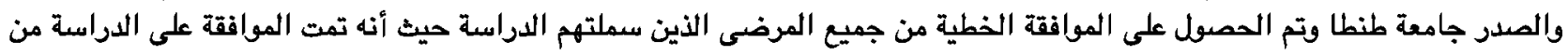
قبل لجنة الأخلاقيات بكلية الطب جامعة طنطا.

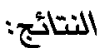

- وجود أرتباطاً إيجابياً بين مستويات (أن تى- برد بى أن بى) وكل من عمر المريض وأحتياجه لمنشطات القلب وذمن إغلاق الثريان

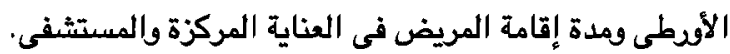

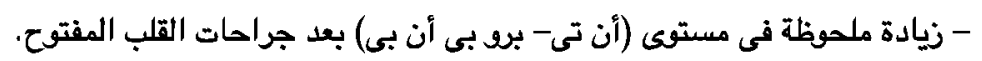

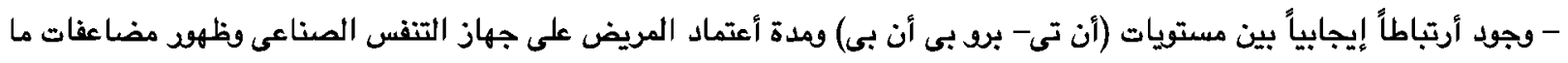
بعد جراحات القلب المفتوح.

الأستتاج: أرتباطُ مستوى (أن تى - برو بى أن بى) أرتباطاً قوياً مع ظهود مضاعفات ما بعد جراحة، مما يشير إلى قيمته كمؤشر فى التبؤ. بالنتائج فى وقت مبكر بعد جراحة القلب. 